\section{Muafi $^{1}$ Qurotul Uyun}

\title{
THE ALIGNMENT OF INNOVATION STRATEGY, ISLAMIC HRM (IHRM) PRACTICES, AND ORGANIZATIONAL PERFORMANCE: A CONTINGENCY APPROACH
}

\begin{abstract}
The aims of this study are to test and analyze the level alignment of innovation strategy (incremental and disruptive) with Islamic HRM (IHRM) Practices on Batik MSMEs (micro small medium entreprises) in Pekalongan, especially its environmental, social, and religious performance. Pekalongan is known as Batik creative city worldwide and has a good innovation breakthrough. The sample of this study is most of the owners/managers of Batik MSMEs in Pekalongan by using purposive sampling technique. Samples are divided into two groups using mean split approach, namely MSMEs that choose the incremental innovation strategy and MSMEs that choose disruptive innovation strategy. The statistic technique is using Euclidience Distance Regression. Semantic differential scale is used as variable measurement technique. The result tested by using bivariate model fit approach shows that there is an alignment/fit between incremental innovation strategy with conservative IHRM Practices and Organizational Performance, and on the other hand there is an alignment between disruptive innovation strategy with innovative IHRM Practices and Organizational Performance. This study provides a theory implication related to the importance of having a level of alignment of innovation strategy with IHRM Practices and Organizational Innovation. The managerial implication is MSMEs should have a strategy and innovation policy aligned to the implementation of IHRM Practices in company operation so that the organizational performance can be increased.
\end{abstract}

Keywords: Incremental Innovation, Disruptive Innovation, IHRM Practices, Organizational Performance

\section{Introduction}

Schuler and Jackson (1997) say that managing human resources involves everyone and requires a lot of time. Companies should solve existing problems while maintaining a long-term outlook and continue to improve the ways of working so that the desired results can be obtained quickly. Managing human resources in the $21 \mathrm{st}$ century includes; (a) manage employees, policies and practices that used by companies now, and (b) manage the forces of change (such as technology, 
business, legal and social restructuration and others) that the organization must examine in order to position itself in the 21st century.

Batik MSMEs in Pekalongan are required to be able to manage their human resources so they have value and strategic. Pekalongan City is well-known as the world's creative city since 2014. Pekalongan is the only world batik city established by UNESCO representing Indonesia. Batik is a local wisdom product of Pekalongan city which also becomes the city's branding or slogan namely "Bersih Aman Tertib Indah Komunikatif" (B.A.T.I.K). Besides that, Pekalongan is known as the santri city because it has a thick religious atmosphere. Although the majority of the community is Muslim, it has a high level of pluralism. It can be seen from the community who can live side by side and transact business with Tionghoa and Arab communities (Sofiani, 2016). Year after year,the growth of Batik MSMEs in Pekalongan City continues to increase. Some places that become centers of batik in Pekalongan city have spread to several regions. The practice of Islamic Human Resources in Pekalongan is a strategic aspect to study because the city is able to survive managing batik business in decades by applying the living in harmony principle. It seems that Islamic religious values have been practiced by Batik MSMEs in carrying out their business. However, have they implemented the the organization strategy on target? This study is examine the importance of conforming innovation strategies both incrementally and disruptively related to the IHRM practice in Pekalongan Batik SMEs in improving organizational performance.

\section{Literature Review}

\subsection{IHRM Practice, Innovation Strategies and Organizational Performance}

In general, the practice of human resource management will be related to recruitment, selection, development, compensation, retention, evaluation and promote personnel within the organization (Bernadin and Russell, 1993). Walters (1985) and Werther \& Davis (1996) state that human resource management is the life of an organization that focuses on management and the effective use of people to increase productive contributions to the organization through strategic, ethical and accountable ways. In addition, Schuler and Huber (1993) argue that the human resource practices are specific actions that are used to attract, motivate, and retrain the workforce for general human resource activities (planning, staffing, assessment, compensation, training, development, establishing and maintaining effective working relationships).The activities involved in human resource management are very diverse and can be grouped into six policy areas. The six policy areas are:

1. Organizational design, including; human resource planning, job analysis, job design, working groups and information systems

2. Staffing, including; recruitment/interview/rental, approval action, promotion/separation/transfer, outplacement service, induction/orientation and labor selection method,

3. Communication and Public Relations, including;

records/report/information system, labor communication, suggestion system, and personnel research,

4. Performance management, including; management assessment/management by objective assessment, productivity program/expansion and consumer oriented performance assessment,

5. Fulfillment, benefit and reward system, including; safety programs, health/clinical service, complaint 


\section{Intermational Quality Conference}

procedure, compensation administration, Equal Employment Opportunity Commission compliance, wage/salary administration, insurance administration, unemployement compensationadministration,

retirement/profit sharing programs, collective bargaining,

6. Labor and organizational development, including; management development, career planning, labor assistance programs/counseling, skill training, layoff readiness programs and attitude surveys.

These six activities of human resource practices are very difficult to judge good and bad because they are difficult to implement. This is because the company depends on the policy characteristics, procedures and strategies that organization choose. Errors in the selection of organizational strategies will have a negative impact on company performance. Tsui (1987; Tsui et al., 1997) suggests three theoretical perspectives on human resource management practice and policy, including;

1. The structural functionalism perspective, which states that the human resource management department and all its activities are the result of organizational growth and/or the need to carry out activities who conducted by a specialist.

2. The strategic contingency perspective, which views human resource management as a creative manifestation of increasingly critical external pressure.

3. The human resource management strategy perspective, which is human resource management activities are designed to support the company's strategic objectives in an integral manner.

The development of current human resource management practices implementation is directed to manage and utilize strategic human resources to achieve organizational goals. Consequently, managers in the company must pay attention whenmanaging human resources. Human resources management must be carried out effectively and efficiently to achieve organizational goals by increasing organizational performance.

When determining human resource practices related to competitive strategies, organizations can choose several dimensions of appropriate human resource practices (Schuler and Jackson, 1997). Some dimensions of human resource practices can be a standard for choosing human resource practices which is consist of five main activities; planning, placement, assessment, compensation, training, development and management relations. While Delaney and Husehild (1996) views that the dimensions of the progress of human resource management practices are in line with those of Schuler and Jackson (1987), which explain, among others;

1. Staffing selectivity method. Managers can implement selective placement methods for all levels such as operational, supervisory and managerial employees.

2. Training effectiveness. A well-planned training programand evaluated training programconsistently. Organizations have formal training programs, and are not only sporadic or insidential.

3. Incentive compensation dimensions are one of motivation factors that affect employee performance, so that it will affect organizational performance (Ulrich et al., 1991). A good and fair compensation system is the main driver of employee motivation.

4. Grievance proceduredimensions in an organization will provide a calmsense, security and motivate employees to work if conducted openly and fairly for all parties. 
5. Decentralized decision making will form work structure that is able to improve the company work by providing opportunities for skilled and highly motivated employees to involve themselves in determining what work to do and how to do it. The involvement of the labor to determine methods and how to complete their tasks can lead to better organizational performance.

6. Internal labor market dimensions are policies within the organization when carrying out promotions. The same opportunity in obtaining a promotion can provide a sense of security for the work they have, so that employees can work well which affects organizational performance.

7. The vertical hierarchy dimension is a level within the organization that gives promotion opportunities to all employees. This provide security for work.

The implementation of progressive human resource practices will show the organization has administrative innovation power. Progressive human resource practices are part of administrative innovations within an organization.

Alorfi (2012 in Malik (2016) says that IHRM is closely related to Islamic management theory which has characteristics including: (i) Islam provides comprehensive guidance on all aspects of life, (2) Islamic principles are always based on Al Quran and Hadith, (3) HRM should be based on the instructions provided by the Islam, (4) effectiveness will depend on the appropriateness of the principles and theoriesapplication.

Ab Rahman et al. (2013) have examined and categorized IHRM practices into 5 activities: (1) recruitment and selection, (2) knowledge and understanding Islamprinciples, training and development, (4) performance assessment, and (5) reward and compensation. All of them based on Qur'an and Hadith which is emphasize three things: Aqidah (belief in Islam), worship (prayer) and muamalah (relationship between people). The IHRM practice in this study refers to the Huselid et al. (1997) typology which states that human resource management practice is divided into two: strategic (innovative) human resource management practices and technical human resource management (efficiency) practices. This division is based on regulatory functions and administrative process. The practice of human resource management techniques emphasizes regulatory functions and administrative processes, while strategic human resource management practices emphasize empowerment and social interaction functions. To achieve or develop specific competitive advantages, effective technical human resource management is needed. However, to achieve competitive advantage process, the practice of technical human resource management is not enough, strategic human resource management practices are also needed.

Human resource management practices have generally been conducted in the company. This practice is easily copied by competitors because most of these practices are traditional. So that the human resource management practice has not guaranteed the company to obtain sustainable benefits, so it does not have a competitive advantage. Therefore, strategic human resource management is needed. Strategic implementation will be carried out successfully if it produces fit conditions with the company's external and internal environment (Huselid et al., 1997; Delaney and Husehild., 1996). In the Schuler and Jackson study (1987), it is explained that there was a correlation between innovation competitive strategies, quality enhancement, and cost reduction with HR practices that were in accordance with the competing strategies. The human resource management practice plays an important role in meeting 


\section{Interinational Qualitity Conference}

the employee's expectations to increase their selling value in the long term (Alster, 1989 in Schuler and Jackson, 1997: 14). The choice of the human resources practice must be careful because the selection of human resource practices will have a strong influence on behavior. If used wisely (systematically with the needs of consumers, employees and the company's business strategy), this kind of practice will change the low-level performance companies into high-level performance companies.

In this study the innovation strategy typology refers to Kataria (2013), namely incremental innovation and disruptive innovation. Incremental innovation is characterized by: (1) red ocean strategy, (2) market driven, (3) value improvement, (4) market improvement, (5) conventional logic, (6) conventional mindset of planning. Whereas disruptive innovation is characterized by; (1) blue ocean strategy, (2) market driving, (3) value creation, (4) market creation, (5) value innovation logic, (6) theory focused planning. Incremental innovation has the identical characteristics of Schuler's and Jackson's (1987) cost reduction strategies while disruptive innovation has characteristics that are identical to innovation. The results of several studies conclude that there is a relationship between $\mathrm{HR}$ practices and competitive strategies in improving company performance. Changing HR practices without making business changes can be unwise, except for companies that have not managed HR effectively. Therefore, changing HR practices requires time, patience and confidence to be success (Bjorkman and Xiucheng, 2002; Weinsten and Obloj, 2002; Werbel and DeMarie, 2005; Twomey and Harris (2000).

Heijltjes and Witteloostuijn (2003) conclude that a market environment which is characterized by cost control and minimize marketing forces should adopt a cost leadership strategy (Porter, 1980) or strategy defender (Miles and Snow, 1978), use manufacturing technology modification and implement traditional/non-progressive HRM. Conversely, a market environment which is characterized by innovation and minimize marketing forces should adopt a differentiation strategy (Porter, 1980) or prospector strategy (Miles and Snow, 1978), and employ flexibility or technological innovation in manufacturing and implement HRM / progressive development.

\section{H1. The more an alignment incremental innovation strategies and conservative IHRM Practice, the more increased organizational performance.}

H2. The more an alignment disruptive innovation strategies and innovative IHRM Practice, the more increased organizational performance.

\section{Research Methodology}

The survey conducted in Pekalongan City, Central Java. The study population focused on the entire Batik MSMEs in 18 urban villages. The Islam practice has indirectly been applied because the city is known as a city that has majority of Muslims and live side by side with other ethnicities. Sampling technique wasconducted by purposive sampling technique. The criteria are; MSMEs that have operated for at least 2 years and oriented towards innovation strategies. The MSMEs studied were batik MSMEs in Pekalongan that innovated in the orientation of natural and synthetic color batik, which amounted to 151 MSMEs. In measuring the IHRM Practices and organizational innovation strategies (IO), researchers use semantic differential scale starting from scale 1 (very not stressed) to scale 7 (very stressed). Generic HRM practices in this study have been combined with Islamic Value so that Islamic terms have been added in each HRM practice to avoid confusion. 
Whereas organizational performance (OP) is measured by asking the owners/managers perceptions to compare their performance with competitor performance, in the last 2 years on a scale of 1 (very low) to scale 7 (very high). Organizational performance includes; environmental, social and religious performance. The innovation strategy is divided into two: incremental and disruptive. Distribution is conducted by mean split. If the actual score results of the strategy are $\geq 3.5$ then it is include in disruptive innovation, vice versa. The statistical technique uses Regression Euclidience Distance by looking at a simple linear regression coefficient (contingency approach). Negative and significant coefficient numbers are sought because the greater the ED score means that the intervariable fit is smaller so that it will negatively affect organizational performance. This indicates that it will improve organizational performance, vice versa. The validity and reliability testing results of the items and the variables are valid and reliable.

Table1.Incremental group regression result $(\mathrm{n}=91)$ \& Disruptive $(\mathrm{n}=60)$

\begin{tabular}{|l|c|c|c|c|}
\hline $\begin{array}{c}\text { Regression equation } \\
\text { model }\end{array}$ & $\begin{array}{c}\text { Consta } \\
\mathrm{nt}\end{array}$ & $\begin{array}{c}\text { Coeffisien } \\
\text { ts (beta) }\end{array}$ & $\mathrm{t}$ & sign \\
\hline $\begin{array}{l}\text { 1. Y = a + b1 dist } \\
\text { (Strat.Increm.IHRM) } \\
+\mathrm{e}\end{array}$ & 6.304 & -0.257 & - & 0.014 \\
& & & $\begin{array}{c}2.51 \\
0\end{array}$ & \\
\hline $\begin{array}{l}\text { 2. Y = a + b1 dist } \\
\text { (Strat.Disrupt.IHRM } \\
\text { +e }\end{array}$ & 6.088 & -0.379 & - & 0.003 \\
& & & $\begin{array}{c}3.12 \\
2\end{array}$ & \\
\hline
\end{tabular}

note:* sign.

$<0.05$

\section{Results and Discussions}

\subsection{Results}

This study uses organizational strategy data of 151 MSMEs that choose incremental and disruptive strategies. Furthermore, the overall data will be divided into two groups of strategies with the 3.5 mean split approach (range of scores 1 to 7 ); (1) incremental strategies of 91 MSMEs, and (2) disruptive of 60 MSMEs. Both groups were tested using anova model (analysis compare means one way ANOVA). The test result shows that there is significant differences between incremental strategies (code 1) with disruptive strategies (code 2) with sign $\mathrm{F}=$ 0.00 .

The hypotheses tested by using simple linear regression model with the equation, $\mathrm{Y}=\mathrm{a}+$ bDist + e. Where $\mathrm{Y}$ is organizational performance, $a$ is a constant; $b$ is the regression coefficient; Dist is the Euclidian distance variable. In a simple linear regression equation each independent variable euclidian distance is tested for its effect on organizational performance and the results are summarized in Table 1 . It can be concluded that hypotheses 1 and 2 are accepted because both have significance below 0.05 .

\subsection{Incremental and Disruptive Innovation Group Regression Analysis}

The regression test results shown in Table 1 are testing hypotheses 1 and 2 in the incremental and disruptive innovation strategy groups.

\subsection{Discussion}

The results prove that there is a match between incremental innovation strategies and conservative IHRM Practice so that it can improve organizational performance. Likewise, there is an aligment between disruptive innovation strategies and innovative IHRM so that it can improve organizational performance. This finding also reinforce Tsui (1987) that any organizational strategy chosen in the implementation of current human resource management practices must be directed at the management and utilization of strategic human resources to achieve organizational performance. Based on strategic contingency 


\section{Intermational Qualilty Conference}

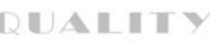
RIISSIEAIRCI

perspective, human resources management is a creative manifestation of increasingly critical external pressure. Do not let the company make a mistake in setting its strategy because it will have a negative impact on the organizational performance, especially on environmental, social and religious performance. Consequently, MSMEs Batik Pekalongan managers/owners must pay attention to their HR practices. The findings of this study also prove Kataria (2013), Bjorkman and Xiucheng, 2002; Weinsten and Obloj, 2002; Werbel and DeMarie, 2005; Twomey and Harris, 2000).

When a company establishes an incremental innovation strategy, the Islamic HRM Practices must be adapted to the strategy of implementing conservative IHRM, and vice versa. Pekalongan City is well-known as a city which is mostly use syntheticcolor. The advantages of this synthetic color are; it's easy to find the raw material, very varied, and cheaper but it's not healthy and doesn't last long. This condition is experienced from year to year so companies prefer to operate in existing competition, market driven and conventional both from planning and implementation. However, now it turns out that some Batik MSMEs have begun to direct their efforts to batik that is natural colorsoriented. The advantages of these natural colorsare healthier and long lastingbut the ingredients are more difficult to find. It seems that they are more aware of environmental and social performance which is accompanied by the religious performance that will be produced.

The implemented IHRM is still very conservative, namely; the usual business process, administrative and prioritizing rigid rules. The IHRM practice highlights (1) the recruitment and selection of noble batikmakers while still emphasizing efficiency, (2) self-taught learning with cost efficiency considerations, (3) conducting training in collaboration with agencies that provide free training, (4) performance assessment based on work results and has not provided other compensation (religious tourism), and (5) gives non-material rewards (visits sick employees). The result shows that Batik MSMEs that use conservative innovation strategies and choose efficient IHRM emphasized efficiency aspects so that organizational performance increased. Likewise, Batik MSMEs that use disruptive innovation strategies prefer innovative IHRM which emphasizes the progress/innovation of IHRM practices so that organizational performance also increases. Innovation in IHRM emphasizes more on aspects (1) recruitment and selection that emphasize the quality of noble batik-makers, (2) professional learning in professional institutions, (3) motivating employees with material and non-material compensation, (4) performance assessment based on work results and giving bonuses, and (5) giving material (religious tourism) and non-material awards. Both of these IHRM practices based on Qur'an and Hadith which emphasize three things; aqidah (belief in Islam), worship (prayer) and muamalah (relationships between people). The end result is more directed at the importance of increasing environmental, social and religious performancebecause it is based on the principle that life in the world is not only seeking profit but must be beneficial for the environment and society.

\section{Theory And Managerial Implication}

Theory. Reinforce theory contributions on the importance of alignment level of innovation strategy. Conservative innovation strategies will be appropriate if the company implements IHRM Practices which emphasize efficiency aspects, and vice versa. It will have an impact on improving organizational performance especially on environmental, social and religious performance.

Managerial. The IHRM practice must be 
taken seriously. This practice must be balanced with the conformity level of the strategies implemented by the company. The impact expected is increased economic growth, reduce unemployment and reduce poverty in the long term.

\section{Acknoledgement}

We are thankful for the Directorate of Research and Community Service, Ministry of Research and Technology of the Republic of Indonesia for funding this study in the TA Basic Research Grant scheme. 2019/2020. We are also thankful for DPPM UII as the institution that gave approval to conduct this study.

\section{References:}

Ab. Rahman, N.M. N., Alias, M.A., Shahid, S., Hamid, M. A., and Alam, S.S. (2004). Relationship between Islamic Human Resource Management (IHRM) practices and trust: An empirical study, Journal of Industrial Engineering and Management, 6(4): 1105-1123.

Bernadin, H.J dan Russel, E.A. (1998), Human Resources Management; An Experiental Approach, Second Edition, International Editions, McGraw-Hill Companies, Inc.

Bjorkman, I., and Xiucheng, F. (2002), HRM and the performance of Western firms in China, International of HRM, 13: 7 November, p. 1042-1059.

Delaney, J.T., \& Husehild, M.A. (1996). The Impact of Human Resources Management Practices on Perceptions of Organizational Performance, Academic of Management Journal, Vol. 39, No. 4, p. 949-969

Heijltjes, Marielle., Arjen van Witteloostuijn (2003), Configurations of market environments, competitive strategies, manufacturing technologies, and human resources management policies A teo industry and two country analysis of Fit, Scandinavian Journal of Management, 19, p. 31-62.

Huselid, M. A., Jackson, S.E., and Schuler, R.S. (1997), Technical and Strategic Human Resource Managementt Effectiveness as Determinant of Firm Performance, Academic Management Journal, Vol 40, No. 1, p. 171-188.

Kataria (2013). Strategic Innovation. A review and Theoritical Framework. Thesis, University of Twenty.

Porter, M.E., (1994), Keunggulan Bersaing: Menciptakan dan Mempertahankan Kinerja, Binarupa Aksara, Jakarta.

Rana, M.H., and Malik, M.S. (2016),"Human resource management from an Islamic perspective: acontemporary literature review", International Journal of Islamic and Middle Eastern Finance and Management, Vol. 9, 1, pp.109-124.

Schuler, R. S., \& Jackson, S.E. (1987). Linking competitive strategy with Human Resources Management Practices, Academic of Management Executive, I (3), p. 207-219

Schuler, R.S., and Huber, V.L. (1993). Personnel and human resource management, West Publishing Company, USA

Sofiani, T. (2016). Perilaku Curang Dalam Transaksi Bisnis Batik di Kota Pekalongan, The 3rd University Colloquium, p. 197-206.

Tsui, A., Peacre, J., Porter, L and Tripoli, A. (1997). Alternative approaches to the employeeorganization relationship: Doesinvestment in the employees pay off? Academy of Management Journal,40,1089-1121.

Tsui, A. (1987). Defining the Activities and Effectiveness of the Human Resource Department: A Multiple Constituency Approach, Human Resource Management, March, 26(1):35 - 69

Twomey, Daniel F and Drew L. Harris (2000), From Strategy to Corporate Outcomes: 
Aligning Human Resources Management System with Entrepreneurial Intent, International Journal Of Commerce and Management, Vol. 10, pp. 43-55.

Ulrich, D (1997), Human Resources Champion, Boston, MA; Harvard Business School Press.

Walker, J. W. (1992), Human Resources Strategy, McGraw Hill Inc, Singapore

Weinsten, M., and Obloj, K. (2002), Strategic and environmental determinants of HRM innovations in post socialist Poland, The International of HRM 13:4 June, p. 642-659.

Werbel, J. D., and DeMarie, S.M. (2005), Aligning strategic human resources management and person-environment fit, Human Resources Management Review, 15(4):247-262.

Werther, Jr WB and Davis, K. (1996), Human Resources Management and Personnel Management, Fifth Edition, Irwin McGraw Hill, USA.

\section{Muafi}

Universitas Islam Indonesia, Department of Management, Economic Faculty

Jl. Ringroad Utara

CondongCatur Yogyakarta

Indonesia

$\underline{\text { muafi@uii.ac.id }}$

\section{Qurotul Uyun}

Universitas Islam Indonesia,

Faculty of Psychology \&

Social Culture Sciences

Jl. Kaliurang KM. 14,5 Sleman

Yogyakarta

963200102@uii.ac.id 


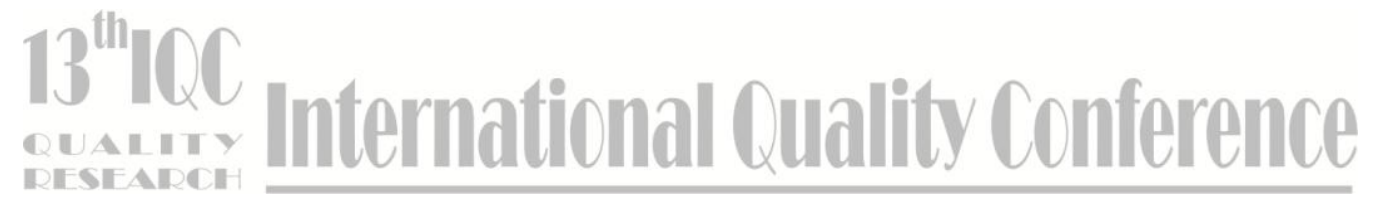

